\title{
Influence of melting and casting conditions on the structure and properties of sacrificial anodes
}

\author{
V. Kechin ${ }^{1}$ and E. Lyublinski ${ }^{2}$ * \\ ${ }^{1}$ Vladimir State University, ul. Gor'kogo, 87, Vladimir, 600000 Russian Federation \\ ${ }^{2}$ COR/SCI, LLC, 6421 Dorset Ln., Solon, OH 44139, USA \\ *E-mail:elyublinski@gmail.com
}

\begin{abstract}
Broad application of aluminum, magnesium and zinc alloys used for production of cast galvanic anodes (GA) is well known in the systems for corrosion protection of metal constructions and structures in sea water, soil, etc. The main requirement of the standards for various brands of protective alloys is their chemical composition (content of alloying components and maximum permissible concentrations of major cathodic impurity elements) that defines the electrochemical properties of alloys (working potential, current output and capacity). In terms of industrial production any deviations of technological parameters for melting and casting, found in various combinations, have a negative impact on both content of the non-regulated impurity elements (dissolved hydrogen, oxide inclusions, etc.) and on the structural homogeneity of cast anodes. This explains the conflicting data about the effectiveness of individual cast anodes made from one alloy grade and even one melting. Based on theoretical and experimental research, the role of metallurgical (provision of specified chemical composition and purity of alloys) and technological (ensuring homogeneous cast structure) factors in changing the quality of cast anodes was found. To provide specified and stable protective properties of aluminum, magnesium and zinc sacrificial anodic alloys technological processes of melting and casting were developed, which take into account the physicochemical nature of alloys, as well as design, weight and dimensions of the cast anodes. Presented are the main properties of modified sacrificial anodic alloys in sea water and soil.
\end{abstract}

Keywords: magnesium, aluminum, zinc, alloys, contaminants, microstructure, metallurgy, anodes, cathodic protection, sea water, soil, production.

Received: July 23, 2017. Published: August 4, 2017.

doi: $\underline{10.17675 / 2305-6894-2017-6-4-1}$

\section{Introduction}

One of the most promising means of the electrochemical corrosion control of metal constructions is the cathodic protection using cast sacrificial alloys (sacrificial anodic materials - SAM) based on $\mathrm{Mg}, \mathrm{Al}$ and $\mathrm{Zn}$ [1-8]. Cathodic protection is used for corrosion protection of a wide range of metal equipment in natural environments (mainly in sea water and soil), including the hull and the inner surfaces of ships and tankers, ballast tanks 
and reservoirs, ground and underground storage tanks, as well as underground and underwater pipelines, offshore platforms equipment in the defense, oil and other sectors of the industries.

Great achievements in development of new corrosion protection systems that combine sacrificial anodes and inhibitors allowed the efficiency and service life of corrosion protection to be increased significantly [9-12]. In these cases it is extremely important to increase the capacity (current output) of sacrificial anodic alloys. With regard to the increased complexity of the operating conditions of various metal structures, the creation and application of the metallurgical technologies, that will increase the efficiency and service life of corrosion protection is one of the most worldwide important industrial problems $[13,14]$. One of the most worldwide promising and effective means of combating the electrochemical corrosion of metal structures is cathodic protection using anodes from cast sacrificial anodic alloys (SAA), by itself and in combination with corrosion inhibitors. This combination allows one to increase efficiency and service life of corrosion protection and significantly decrease cost of the system.

The operation experience of cathodic protection systems with sacrificial anodes has shown that with all other things being equal, the anodes of one grade often have a different service life. One of the major causes of electrochemical heterogeneity of the metalelectrolyte systems are internal factors related to the nature of the metal, its composition, structure, etc. (Table 1).

Table 1. The main groups of factors influencing the quality of cast anodes in production environment.

\begin{tabular}{ccc}
\hline Group of factors & The determining factor & Designation factor \\
\hline & $\begin{array}{c}\text { - selected chemical composition: composition and } \\
\text { condition of the furnace lining or crucible material } \\
\text { - the composition and quality of the used composition, } \\
\text { the procedure for loading the components } \\
\text { - the temperature-time melting mode } \\
\text { the alloy }\end{array}$ & $\boldsymbol{X}_{\mathbf{1}}$ \\
& - the process of refining & $\boldsymbol{X}_{\mathbf{3}}$ \\
& - structure: & $\boldsymbol{X}_{\mathbf{4}}$ \\
\hline $\begin{array}{c}\text { Metallurgical-foundry, } \\
\text { that defines the structure } \\
\text { of the cast protectors }\end{array}$ & - conditions and the intensity of heat removal & $\boldsymbol{X}_{\mathbf{5}}$ \\
\hline $\begin{array}{c}\text { Foundry quality of the } \\
\text { anodes }\end{array}$ & and size of the anode & $\boldsymbol{X}_{\mathbf{6}}$ \\
\hline
\end{tabular}

Metallurgy factors. Any variation of the technology parameters during the melting and casting has an impact on the change in the composition of the alloys and the degree of development of the chemical and structural homogeneity of the cast anodes. Apparently this can explain the decline and destabilization of the anodes electrochemical properties 
occurring in the early stages of application, as well as conflicting data about the effectiveness of individual anodes from one grade. In other words, the degree of heterogeneity of the electrochemical protectors can change during melting and casting, based on the foundry factors, such as change of the chemical composition of the alloy or change of technological parameters for smelting and casting.

In assessing the quality of SAA and these anodes, the factors that largely depend on their properties were defined. Depending on the composition and quality of the lining of the furnace or crucible material $\left(X_{1}\right)$, changes in the chemical composition of the alloy are possible, related to loss of alloying components and saturation of the melt with gases and nonmetallic inclusions.

Composition and condition of the charge, as well as the procedure for loading the components $\left(X_{2}\right)$ are critical in obtaining high-quality alloys. Given that SAA of high purity should have very limited content of harmful impurities of cathode the quality of burden materials should be monitored.

You must bear in mind that the state of charge can change some properties of the alloys. According to our data presented in [15-18] in charge of various numbers of return and previously deformed charge leads to a change in the actual current output of the alloys based on magnesium and zinc. Thus, depending on the State of charge and load order of components $\left(X_{2}\right)$ there can be deviations from the specified alloy chemical composition in the content of alloying elements. Temperature-time melting mode $\left(X_{3}\right)$ is an important factor associated with a deviation from the specified alloy chemical composition.

It is known that overheating of the melt leads to the combustion of components, especially fusible ones, and, as a consequence, to a change in the chemical composition of the alloy; insufficient heating - to the segregation of individual components of the charge, especially refractory and difficult-melting with the base of the alloy. A long duration of melting, prolonged mixing of the melt, in addition to carbon black, lead to oxidation and contamination of the melt with gases and oxide inclusions. In all cases, it is necessary to strive for an accelerated melting regime. Before refining, the surface of the melt should be cleaned of oxides and slag to avoid contamination of the melt $\left(X_{4}\right)$. Enter refining additives or fluxes in strict accordance with the technology of the operation. The consumption of the refining reagents depends on the initial purity and nature of the alloy.

Metallurgical-foundry factors provide the possibility of obtaining a homogeneous crystal structure. Applying the modifying operation $\left(X_{5}\right)$ when melting the SAA, it is possible to refine the structure of the cast metal. Grinding of grain is especially necessary for multiphase alloys, when it is desirable to have fine uniformly distributed structural components in the alloy structure. Crushing of the internal structure of grains of cast metal is achieved by lowering the casting temperature and increasing the cooling intensity $\left(X_{6}\right)$. The high intensity of the heat removal leads to the formation of a fine-grained structure of the cast metal, and the direction of the heat removal ensures a high degree of homogeneity of the cast structure under these conditions [19-23]. 
Foundry factors ensure the production of a SAA with a specified structure and geometric dimensions. The relatively simple form of castings, to which sacrificial anodes designs belong, tends to exhibit free shrinkage. The numerical value of free shrinkage depends mainly on the nature of the alloy. This factor $\left(X_{7}\right)$ must be taken into account when designing the rigging for SAA of different sizes and weights. Another factor affecting the stability of the properties of cast protectors is the nature of the alloy $\left(X_{8}\right)$. The narrow-interval (ZA1, AA1) and wide-interval (MA1) SAA have a different tendency to form gas-shrinkage defects that affect the parameters and quality of the protectors. The way the metal is fed to the mold also affects the quality of the SAA $\left(X_{9}\right)$. In the casting practice of cast SAA production, taking into account their simple shape, a method of casting metal with different casting conditions is used (3/4 of the volume of the melt is poured in, and the remaining volume of the melt is poured slowly). This mode improves the power of the casting with metal and ensures the smooth surface of the gate part of the protectors.

Non-compliance with metallurgical and casting factors $\left(X_{1}-X_{9}\right)$ leads to the appearance of various defects in alloys and cast SAA. These defects include the deviations in practice of the chemical composition of the protective alloys in terms of the content of alloying elements and harmful cathode impurities, including gas and non-metallic inclusions not regulated by standards. A special place is occupied by defects in cast gash protectors due to dendritic and zonal segregation, heterogeneity of the crystal structure, deviations from the prescribed geometric dimensions of the protectors, and others. The Table 2 shows the main types of defects of protective materials and the reasons for their formation, as well as ways to detect and eliminate them.

Table 2. Main types of defects in sacrificial anodic alloys and methods of their removal.

\begin{tabular}{|c|c|c|c|}
\hline No. & View & The cause of defects formation & How to fix \\
\hline \multirow{3}{*}{1} & \multirow{3}{*}{$\begin{array}{l}\text { Deviation of chemical } \\
\text { composition on the } \\
\text { content of: } \\
\text { > Alloying elements } \\
\text { > Impurity elements } \\
\text { > Non-regulated } \\
\text { inclusions (hydrogen } \\
\text { oxide) }\end{array}$} & $\begin{array}{c}\text { > Violation of temperature and time } \\
\text { parameters of the conditions for the } \\
\text { preparation and cooking of the charge } \\
>\text { Error in the calculation of the whole, failure } \\
\text { to comply with the order of loading of } \\
\text { alloying components; insufficient mixing } \\
\text { duration }\end{array}$ & $\begin{array}{l}\text { Alloy adjustment on } \\
\text { the content of alloying } \\
\text { components }\end{array}$ \\
\hline & & $\begin{array}{l}\text { > Quality of burden materials below the } \\
\text { requirements of the technological instructions } \\
>\text { Violation of coloring (lacquering), and } \\
\text { filling the Crucible instrument } \\
>\text { Long cooking duration alloys }\end{array}$ & $\begin{array}{l}\text { Cleaning melt special } \\
\text { refining additives or } \\
\text { adjustment of high- } \\
\text { purity materials }\end{array}$ \\
\hline & & $\begin{array}{l}\text { Poor quality of refining; insufficient time to } \\
\text { defend melt after refining; high temperature } \\
\text { melt }\end{array}$ & $\begin{array}{l}\text { Repeated refining and } \\
\text { longer defend melt }\end{array}$ \\
\hline
\end{tabular}




\begin{tabular}{|c|c|c|c|}
\hline No. & View & The cause of defects formation & How to fix \\
\hline 2 & $\begin{array}{l}\text { Gas shells and } \\
\text { porosity }\end{array}$ & $\begin{array}{l}\text { Increased gas content of the melt, inadequate } \\
\text { warm-up mortgage details and working } \\
\text { surfaces; failure to comply with the pouring } \\
\text { and solidification }\end{array}$ & \multirow[t]{2}{*}{ Fatal defects } \\
\hline 3 & $\begin{array}{l}\text { Oxide layers and } \\
\text { inclusions }\end{array}$ & $\begin{array}{c}\text { The ingress of oxide films and inclusions into } \\
\text { the mold with a sharp drop in the metal into } \\
\text { the mold cavity during pouring }\end{array}$ & \\
\hline 4 & $\begin{array}{l}\text { Shrinking shells and } \\
\text { micro porosity }\end{array}$ & $\begin{array}{l}\text { Increased casting temperature, insufficient } \\
\text { casting power during the solidification } \\
\text { process; High mold temperature and non- } \\
\text { directional heat sink }\end{array}$ & $\begin{array}{l}\text { Mechanical removal or } \\
\text { humidification of the } \\
\text { gating part of the SAA } \\
\text { containing external } \\
\text { shrinkage shells. } \\
\text { Internal shells, friable } \\
\text { and microrust - } \\
\text { permanent defects }\end{array}$ \\
\hline 5 & Liquation of dendrites & $\begin{array}{l}\text { Non-equilibrium conditions of alloys } \\
\text { crystallization whose components have } \\
\text { distribution coefficients with the alloy } \\
\text { significantly different from unity }\end{array}$ & $\begin{array}{l}\text { Carrying out } \\
\text { homogenizing heat } \\
\text { treatment of cast } \\
\text { anodes }\end{array}$ \\
\hline 6 & Zonal liquation & $\begin{array}{l}\text { The transfer of the liquid mother liquor } \\
\text { enriched with the fusible components to the } \\
\text { skeleton of the alloy crystallizing over a wide } \\
\text { range of temperatures }\end{array}$ & \multirow{3}{*}{ Fatal defect } \\
\hline 7 & $\begin{array}{l}\text { Inhomogeneity } \\
\text { (zonation) crystal } \\
\text { structure }\end{array}$ & $\begin{array}{l}\text { The deviation of the casting temperature from } \\
\text { the preset; Violation of the principle of } \\
\text { directional solidification; The change in the } \\
\text { temperature gradient and the crystallization } \\
\text { rate of the alloy upon solidification; Low } \\
\text { quality of modification }\end{array}$ & \\
\hline 8 & Discontinuities & $\begin{array}{l}\text { Low casting temperature, slow, sometimes } \\
\text { intermittent, filling the mold; Flooding with } \\
\text { two or more threads; High speed of heat } \\
\text { removal from crystallizable metal }\end{array}$ & \\
\hline 9 & Cracks & $\begin{array}{l}\text { Difficult shrinkage of individual parts of the } \\
\text { cast SAA touching the embedded part (due to } \\
\text { low compliance of the embedded part); The } \\
\text { increased temperature of the removed casting } \\
\text { from the mold, when the thermal stress in the } \\
\text { casting exceeds the ultimate strength of the } \\
\text { alloy; Uneven cooling of individual parts of } \\
\text { the casting in combination with the stiffness } \\
\text { of the individual parts of the mold }\end{array}$ & $\begin{array}{l}\text { Fatal flaw, if under the } \\
\text { terms of the } \\
\text { subsequent processing } \\
\text { of defective area is not } \\
\text { removed }\end{array}$ \\
\hline
\end{tabular}




\begin{tabular}{|c|c|c|c|}
\hline No. & View & The cause of defects formation & How to fix \\
\hline 10 & $\begin{array}{c}\text { Deviation from the } \\
\text { specified geometric } \\
\text { dimensions }\end{array}$ & $\begin{array}{c}\text { Wrong choice of shrinkage values of the alloy } \\
\text { in the manufacture of the mold, depending on } \\
\text { the nature of the alloy, the configuration of } \\
\text { the casting and the mold material; Underflow } \\
\text { or overflowing of metal in the mold }\end{array}$ & $\begin{array}{c}\text { In the case of } \\
\text { excessive size of } \\
\text { anodes apply } \\
\text { mechinical processing; } \\
\text { in other cases, the } \\
\text { defect does not } \\
\text { eliminate }\end{array}$ \\
\hline
\end{tabular}

Classification of metallurgical and casting factors that affect the quality of cast SAA and the degree of development of various types of defects indicate that the casting temperature, conditions and intensity of cooling are the most important indicators in melting and casting processes.

Below are the results of experimental studies on the influence of melting and casting conditions on the main properties of protective materials based on magnesium and zinc. Among the known brands of magnesium protective alloys, the alloys of the $\mathrm{Mg}-\mathrm{Al}-\mathrm{Zn}-$ Mn system are most widely used. On the example of the alloy (MP1, GOST 26251-84), the structure and properties of the alloy are considered depending on the casting temperature and the cooling rate. Laboratory specimens with a diameter of $20 \mathrm{~mm}$ and a length of $200 \mathrm{~mm}$ from the alloy MP1 with an impurity content (\%): $0.003 \mathrm{Fe}, 0.001 \mathrm{Ni}, 0.003 \mathrm{Cu}$, $0.005 \mathrm{Si}$ were obtained by casting at 700 and $750^{\circ} \mathrm{C}$ in cast iron molds whose temperature before casting the melt changed from 20 up to $500^{\circ} \mathrm{C}$. Protectors were cast in metal molds with different initial temperatures. Low cooling rates were obtained by heating the mold to $350^{\circ} \mathrm{C}$, which approximately corresponded to casting in a sand mold, and high rates - by constant supply of cooling water through the internal mold cavity. The cooling rate was determined from the ratio of the casting temperature difference and the solidus temperature to the duration of the alloy cooling to this temperature. Comparative electrochemical characteristics of the materials were determined by anodic polarization of the samples in seawater, soil and a solution of activators (Table 3 ) by standard methods.

The results of the studies showed that, regardless of the conditions and test conditions, all samples had a high value of electronegative potentials - stationary $(1260-1290 \mathrm{mV})$ and anodic polarization $(1200-1250 \mathrm{mV})$ relative to the normal hydrogen reference electrode. However, for the same samples, the current capacity (CC) varies from 58.9 to $63.0 \%$, depending on the casting temperature, the cooling rate and the composition of the electrolyte. In seawater and the activator solution, the $\mathrm{CC}$ increases with increasing cooling rate (Figure 1). The greatest increase in $\mathrm{CC}$ is observed at a cooling rate of up to $800^{\circ} \mathrm{C} / \mathrm{min}$. A further increase in the cooling rate slightly modifies the $\mathrm{CC}$ of the alloy. 
Table 3. Electrolyte compositions and test mode.

\begin{tabular}{cccc}
\hline Electrolyte & $\begin{array}{c}\text { Anodic current } \\
\text { density, } \mathbf{A} / \mathbf{m}^{2}\end{array}$ & Test duration, days & $\begin{array}{c}\text { Temperature, } \\
{ }^{\circ} \mathbf{C}\end{array}$ \\
\cline { 1 - 2 } $\begin{array}{c}\text { Synthetic seawater - medium ocean } \\
\text { composition, salinity, } 35 \%\end{array}$ & 5 & 20 & \\
\cline { 1 - 2 } $\begin{array}{c}\text { Soil: } 70 \% \text { sand and } 30 \% \text { clay } \\
\text { with } 10 \% \text { humidity }\end{array}$ & 1 & 15 & \\
\cline { 1 - 2 } $\begin{array}{c}\text { Solution of activator }(\mathrm{g} / \mathrm{l}): \\
\mathrm{MgSO} \cdot 7 \mathrm{H}_{2} \mathrm{O}-54.6 ; \mathrm{CaSO}_{4} \cdot 2 \mathrm{H}_{2} \mathrm{O}-\end{array}$ & 1 & & \\
$3.1 ; \mathrm{NaHCO}_{3}-0.15 ; \mathrm{CaCl}_{2} \cdot 6 \mathrm{H}_{2} \mathrm{O}-$ & & 15 & \\
$0.11 ; \mathrm{Na}_{2} \mathrm{SO}_{4}-21.0$ & & & \\
\hline
\end{tabular}

Increasing the casting temperature from 700 to $750^{\circ} \mathrm{C}$ at the same cooling rate most significantly reduces the MPE of the MP1 alloy in liquid electrolytes. Thus, for the cooling rate of $500-800^{\circ} \mathrm{C} / \mathrm{min}$, the $\mathrm{CC}$ drops from $58-65 \%$ to $53-61 \%$ with a rise in temperature. For low saline soils, an increase in casting temperature during the production of protectors reduces the $\mathrm{CC}$ to a lesser extent.

Investigations of the structure of SAA have shown that an increase in the cooling rate leads to a refinement of the microstructure of the alloy and a more uniform distribution along grain boundaries and in interdendritic spaces of secondary intermetallic phases (Figure 2). An analysis of the results shows that an increase in the $\mathrm{CC}$ of the alloy in seawater and in the solution of the activator is a consequence of the refinement of the structure and a more even distribution of the secondary intermetallic phases, which lowers the rate of self-dissolution of the solid solution by reducing and equalizing the work of local micro-pairs. Similarly, it is possible to explain a slight increase in $\mathrm{CC}$ with a decrease in casting temperature from 750 to $700^{\circ} \mathrm{C}$.

Mathematical processing of the dependencies of the $\mathrm{CC}$ of sacrificial anodic materials in sea water versus the casting temperature $\left(t_{\mathrm{c}}\right)$ and cooling speed $\left(V_{\text {cool }}\right)$ gave the following regression equations:

$$
\mathrm{CC}=f\left(t_{\mathrm{c}}\right) \text { at } t_{\mathrm{c}}=700,750 \text { and } 800^{\circ} \mathrm{C} ; V_{\text {cool }}-\text { constant }=800^{\circ} \mathrm{C} / \mathrm{min}
$$$$
\mathrm{CC}=93.17-0.05 t_{\mathrm{c}} ; \mathrm{CC}=f\left(V_{\text {cool }}\right) \text { at } V_{\text {cool }} \text { in the range from } 100 \text { to } 1600^{\circ} \mathrm{C} / \mathrm{min} \text {; }
$$$$
t_{\mathrm{c}}=700^{\circ} \mathrm{C} \text { (constant) }
$$

$$
\mathrm{CC}=52.69+2.10 \cdot 10^{-2} V_{\text {cool }}-2.39 \cdot 10^{-5} V_{\text {cool }}+8.75 \cdot 10^{-9} V_{\text {cool }}^{3}
$$

The presented regression equations show that the $\mathrm{CC}$ value of the alloy will be the largest at a casting temperature of $700^{\circ} \mathrm{C}$; an increase in the cooling rate also contributes to an increase in the $\mathrm{CC}$ of the alloy.

Below, we consider the structure and properties of zinc alloys depending on the casting temperature and cooling conditions. Samples for research were poured at 450 and $500^{\circ} \mathrm{C}$ 
into metallic and nonmetallic forms. Samples were tested in artificial seawater for 10 days. The test results show that with an increase in casting temperature from 450 to $550^{\circ} \mathrm{C}$ (Figure 3), when casting samples in a nonmetallic form, the $\mathrm{CC}$ of the alloy decreases from 93 to 85 . The same alloy cast in metallic molds with $450 ; 500$ and $550^{\circ} \mathrm{C}$ leads to a change from 94 to $89 \%$.
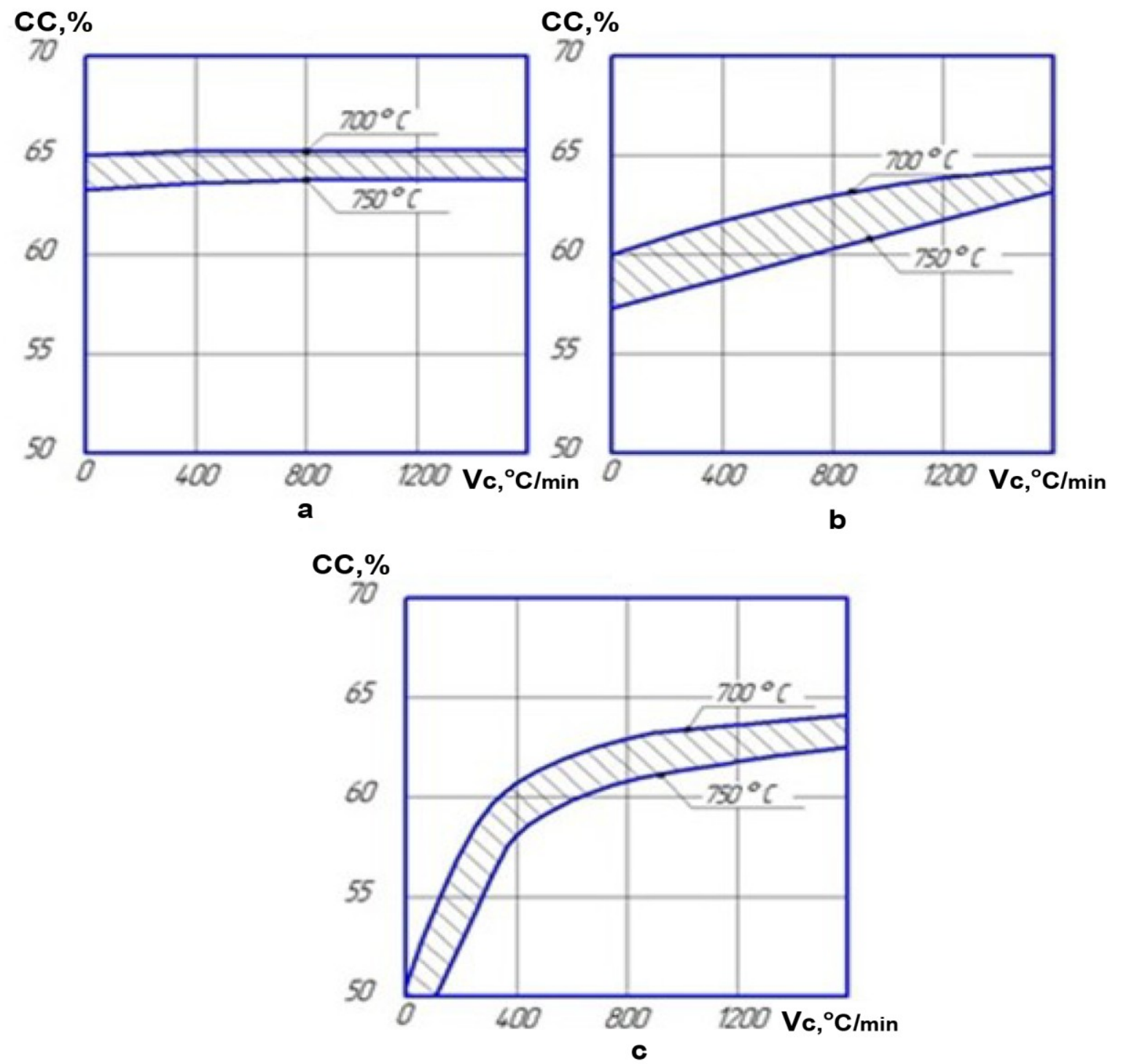

Figure 1. The influence of casting temperature and cooling rate of magnesium alloy MA1 on $\mathrm{CC}$ in soil (a), activator solution (b) and sea water (c). 

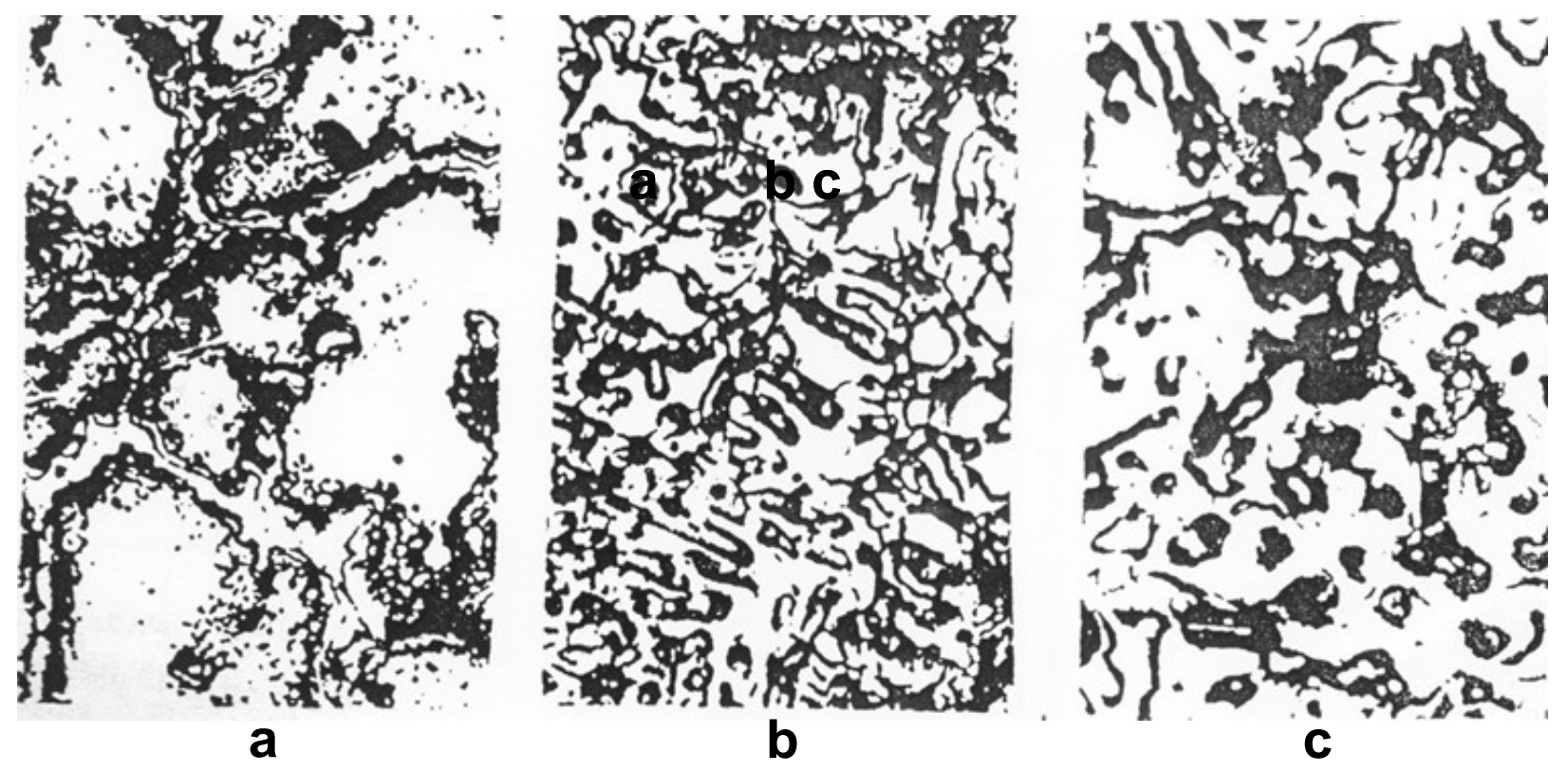

Figure 2. Microstructure $(\times 200)$ of the magnesium alloy at a casting temperatures $700^{\circ} \mathrm{C}(\mathrm{a}, \mathrm{b})$ and $750^{\circ} \mathrm{C}(\mathrm{c})$ and a temperature of the mold $500^{\circ}$ (a) and $100^{\circ}(\mathrm{b}, \mathrm{c})$.
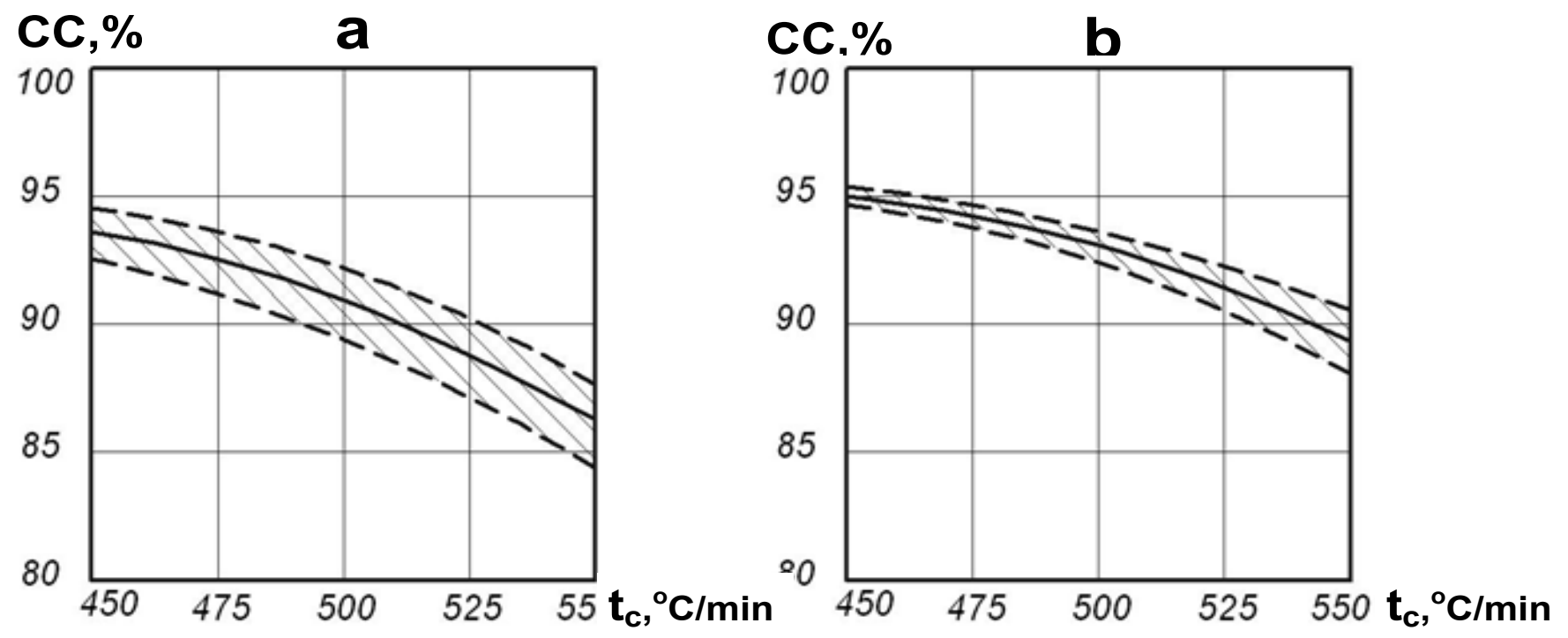

Figure 3. Influence of casting temperature $\left(t_{\mathrm{c}}\right)$ on the alloy $\mathrm{CC}$ by casting in a non-metallic (a) and metallic (b) molds.

The stationary and polarization potentials of the alloy vary slightly with increasing casting temperature when casting samples in nonmetallic and metallic molds. The $-\varphi_{\mathrm{c}}$ value varies within $800-830 \mathrm{mV} ;-\varphi_{\mathrm{p}}$ within the range of $730-760 \mathrm{mV}$. A significant influence on the $\mathrm{CC}$ of alloys is provided by the mold material determining the cooling intensity. When casting in a metallic mold, the $\mathrm{CC}$ is always higher than when casting into 
a nonmetallic mold. The difference in $\mathrm{CC}$ values increases with an increased casting temperature $\left(500\right.$ and especially $\left.550^{\circ} \mathrm{C}\right)$. Obviously, higher and stable SAA properties are achieved by grinding the structure, due to a more even distribution of structural components, which reduces the rate of self-dissolution of solid solutions by reducing and aligning local micro-pairs.

As a result of mathematical processing of the dependence of the $\mathrm{CC}$ of the zinc alloy in seawater on the casting temperature $\left(t_{\mathrm{c}}\right)$, the following regression equation was obtained:

$$
\mathrm{CC}=f\left(t_{\mathrm{c}}\right): \text { at } \mathrm{t}_{\mathrm{c}}=450 ; 500 ; 550^{\circ} \mathrm{C} ;
$$

$$
\text { cooling speed } V_{\text {cool }}=\text { const }\left(150^{\circ} \mathrm{C} / \mathrm{min}\right) ; \mathrm{CC}=127-0.072 t_{\mathrm{c}} \text {. }
$$

On the example of zinc alloys, the change in the basic SAA properties as a function of the cooling rate $\left(V_{\text {cool }}\right)$ at a constant casting temperature of $450^{\circ} \mathrm{C}$ has been studied. To study the effect of the cooling rate on the properties of alloys, the samples were cast into cast iron and nonmetallic molds with an initial temperature of 20 and $180^{\circ} \mathrm{C}$. The rate of solidification of alloys was varied from 20 to $280^{\circ} \mathrm{C} / \mathrm{min}$. The dependence of the $\mathrm{CC}$ of the zinc alloys in sea water from the cooling rate $\left(\mathrm{V}_{\text {cool }}\right)$ upon solidification is expressed by the following regression equation:

$$
\begin{gathered}
\mathrm{CC}=f\left(V_{\text {cool }}\right) ; N=4\left(25,105,230,280^{\circ} \mathrm{C}\right) ; t_{\mathrm{c}}=\text { const }=450^{\circ} \mathrm{C} \\
\mathrm{CC}=84.21+0.035 V_{\text {cool }}
\end{gathered}
$$

Moreover, for the CP1 alloy at a solidification rate of $20-25^{\circ} \mathrm{C} / \mathrm{min}$, the spread of the $\mathrm{CC}$ values will be much larger than at the solidification rate of $220-280^{\circ} \mathrm{C} / \mathrm{min}$ (Figures 4, 5).

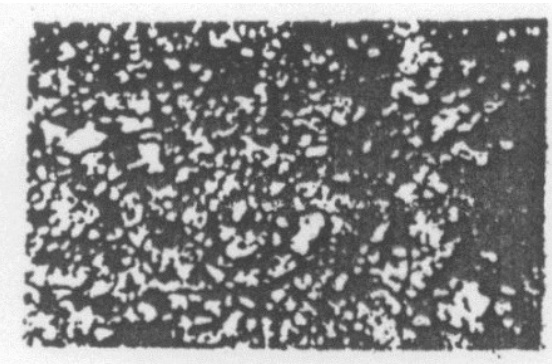

a

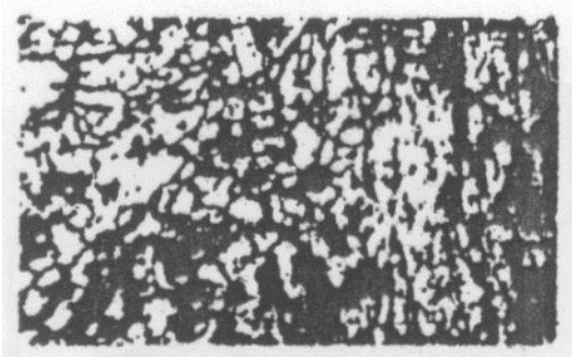

b

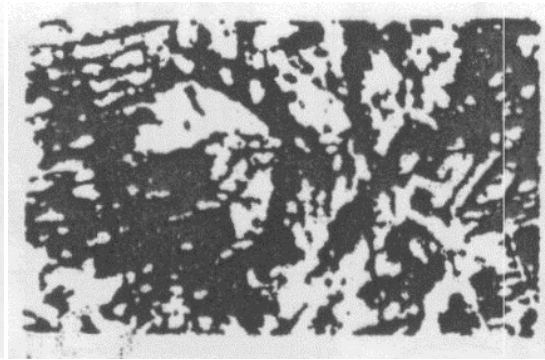

$\mathrm{C}$

Figure 4. Microstructure $(\times 100)$ of zinc alloy by casting in metal mold at temperature $\left({ }^{\circ} \mathrm{C}\right)$ : 450 (a); 500 (b); 550 (c). 


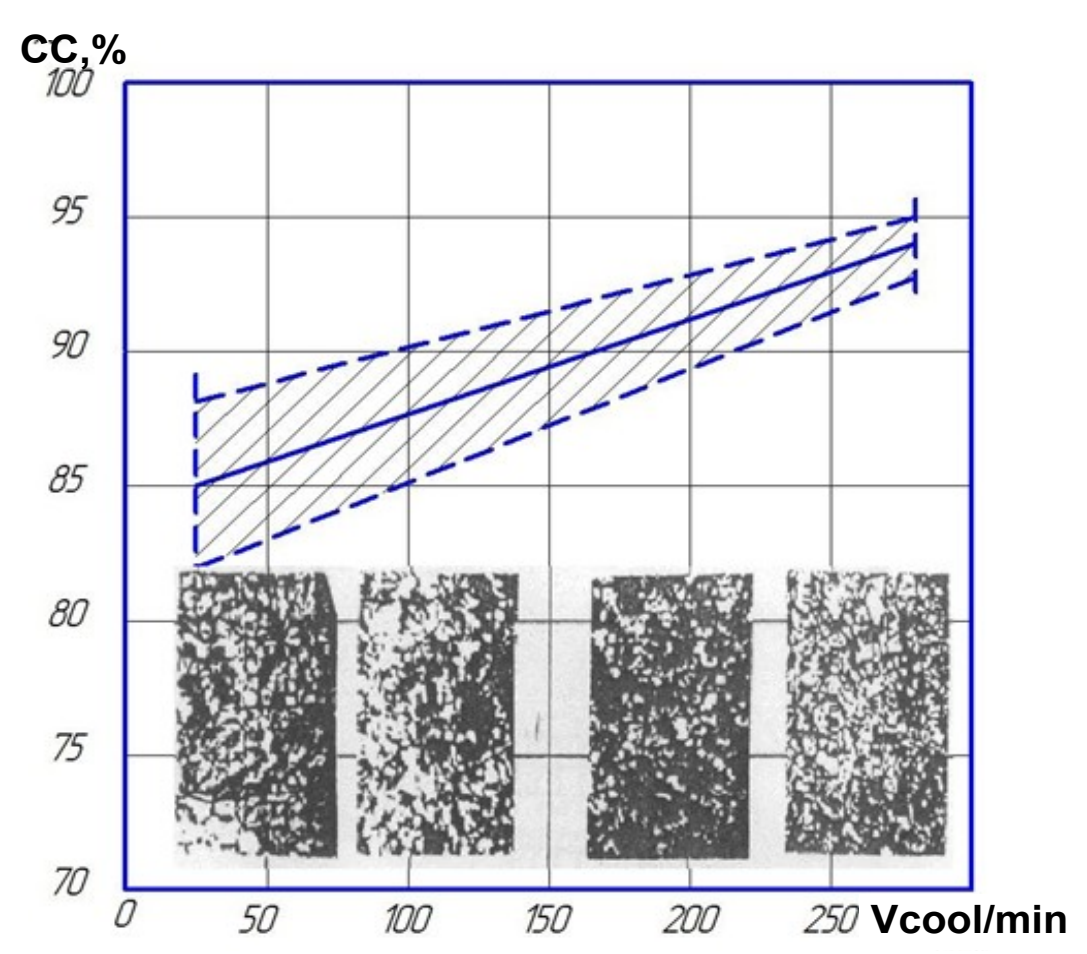

Figure 5. The $\mathrm{CC}$ and microstructure $(\times 100)$ of zinc alloy depending on the cooling rate

The CC values dependencies for magnesium and zinc alloys on the casting temperature and cooling conditions are in good agreement with the data [22] on the impact of temperature-time parameters on the change in the fundamental electrochemical properties of aluminum alloys under industrial production conditions.

The described test procedures are based on fundamental information collected during production and application of magnesium, aluminum and zinc sacrificial anodes for corrosion protection of metallic structures (ships, platforms, pipelines, etc.) in sea water and soil.

\section{Conclusions}

1. The cause of electrochemical heterogeneity of Sacrificial Anodic Alloys is established. It is shown that the degree of electrochemical heterogeneity of SAA materials can change during melting and casting as a result of primary and secondary metallurgical casting factors.

2. A classification of metallurgical and casting factors affecting the quality of tread materials is offered and recommendations are given on how to eliminate defects in treads.

3. The influence of casting temperature and cooling conditions on the structure and main properties of tread materials has been established. It is shown that for standard sacrificial anode compositions MAl (Mg-Al-Zn), ZA1 (Zn-Al) and AA1 (Al-Zn), stable electrochemical characteristics are achieved by forming a homogeneous fine-grained structure with a uniform distribution of structural components. The best conditions for 
obtaining such a structure provided with a casting temperature higher than liquids temperature by $10-15 \%$, as well as when casting alloys in metal mold water-cooled.

4. Recommendations are given on the conditions for obtaining high-quality cast Sacrificial Anodic Alloys under industrial production conditions.

\section{References}

1. V.A. Kechin, Theory and technology of cast sacrificial anodic alloys, Vladimir, VGU, 2008, p. 182 (in Russian).

2. V.A. Kechin. and E.Y. Lyublinski, New Applications Outlook for Magnesium Alloys, EUROCORR 2010, Moscow, Paper 9137.

3. E.Y. Lyublinski, Galvanic Cathodic Protection of Ships and Constructions, Leningrad, Sudostroenie, 1979 (in Russian).

4. E.Y. Lyublinski and V.D. Pirogov, Corrosion and Protection of Ships, Handbook, Leningrad, Sudostroenie, 1987 (in Russian).

5. V.A. Kechin and E.Y. Lyublinski, New Sacrificial Anodic Alloys, EUROCORR 2016, Montpelier, Paper 6542.

6. V.A. Kechin, E.Y. Lyublinski and A.V. Kireev, "The effect of gas content on the corrosion and electrochemical characteristics of aluminum sacrificial anodic alloys," Korroz.: mater., zashch., 2016, no. 2, 1 (in Russian).

7. A. Aghajani, M. Atapour and R. Aubek, "Passivation of zinc anodes in marine conditions," Mater. Perform., 2016, no. 9, 34.

8. S. Pease, "Magnesium anodes manufactured in China," Corrosion Engineering Review, 2017 Edition.

9. I.L. Rozenfeld, E.Y. Lyublinski and Yu.I. Kuznetsov, "Corrosion protection of product side bottoms in crude oil tanks of tankers," International conference "Corrosion and scale inhibitors. To the memory of I.L. Rosenfeld," 2014, Moscow, p. 64.

10. E.Y. Lyublinski, G. Ramdas, Y. Vaks, T.A. Natale, M.H. Posner, K.M. Baker and A. Roytman, Storage tank bottom corrosion protection system, US Patent 9556635, 31.01.2017.

11. S.N. Gusev, A.A. Chirkunov and G.V. Redkina, "Effect of borate buffer solution and $\mathrm{NaCl}$ concentration on anodic behavior of magnesium alloy Elektron WE43 in the presence of inhibitors," Korroz.: mater., zashch., 2017, no. 3, 21 (in Russian).

12. Y.B. Makarychev, I.A. Arkhipushkin, T.A. Karpukhina, K.S. Shikhaliyev and L.P. Kazansky, "Formation of protective Nano Layers on zinc surface by some azoles from aqueous solutions. Part 1," Korroz.: mater., zashch., 2016, no. 2, 20 (in Russian).

13. V.A. Kechin and E.Y. Lyublinski, Zinc Alloys, Moscow, Metallurgiya, 1986, p. 246 (in Russian).

14. V.A. Kechin, E.Y. Lyublinski and V.M. Krilov, "Evaluation of the quality of sacrificial zinc anodic alloys on the basis of analysis of the current state of production," $J$. Shipbuilding Technology, 1978, no. 1, 41 (in Russian). 
15. V.A. Kechin and E.Y. Lyublinski, "The influence of secondary technological factors on the electrochemical properties of zinc treads alloys," J. Shipbuilding Technology, 1980, no. 6, 74 (in Russian).

16. V.A. Kechin, Casting and metallurgical aspects of improving the quality of tread alloys for corrosion protection of sea vessels/ships," J. Shipbuilding Technology, 1981, 21 (in Russian).

17. Yu.I. Kuznetsov, "Progress in the science of corrosion inhibitors," International conference "Corrosion and scale inhibitors. To the memory of I.L. Rosenfeld," 2014, Moscow, p. 6.

18. I.L. Rosenfeld, E.Y. Lyublinski and Yu.I. Kuznetsov, International conference "Corrosion and scale inhibitors. To the memory of I.L. Rosenfeld," 2014, Moscow, p. 91.

19. I.P. Vyatkin, V.A. Kechin and S.V. Mushkov, Refining and casting of primary magnesium, Moscow, Metallurgiya, 1974, p. 191 (in Russian).

20. V.A. Kechin, E.Y. Lyublinski and S.N. Pankratov, "Structure and properties of tread alloys depending on casting temperature and cooling rate," J. Shipbuilding Technology, 1971, no. 8, 120 (in Russian).

21. E.Y. Lyublinski, V.G. Kotik and V.A. Kechin, "The influence of some technological factors on the properties of the magnesium anodic alloy," J. Shipbuilding Technology, 1971, no. 8, 128 (in Russian).

22. A.A. Klusov and V.A. Kechin, "Investigation of the electrochemical characteristics of Al-Zn sacrificial anodes," Liteishchik Rossii, 2008, no. 7, 55 (in Russian).

23. W. Zaifeng, H. Baorong, Z. Jie, W. Xiutong and L. Zhigano, "Optimization of sacrificial anodes for one offshore jacket," Mater. Perform., 2016, no. 2, 20. 